\title{
Morpho-anatomical, Phytochemical and TLC/HPTLC Studies on Whole Plant of Plectranthus vettiveroides (Jacob) N.P. Singh \& B.D. Sharma
}

\author{
Velvizhi D', Nartunai G' ', Susikumar S', llavarasan R',*
}

Velvizhi D', Nartunai G', Susikumar $\mathrm{S}^{1}$, llavarasan $\mathrm{R}^{1, *}$

'Captain Srinivasa Murthy Regional Ayurveda Drug Development Institute, Recognized by University of Madras, CCRAS, Ministry of AYUSH, Government of India, Chennai- 600106, INDIA.

\section{Correspondence}

llavarasan $\mathbf{R}$

Captain Srinivasa Murthy Regional Ayurveda Drug Development Institute, Recognized by University of Madras, CCRAS, Ministry of AYUSH, Government of India, Chennai- 600106, INDIA E-mail: arilavarasan@yahoo.co.in History

- Submission Date: 17-10-2019;

- Review completed: 29-10-2019;

- Accepted Date: 13-11-2019.

DOI : 10.5530/pj.2020.12.10

Article Available online

http://www.phcogj.com/v12/i1

Copyright

(C) 2020 Phcogj.Com. This is an openaccess article distributed under the terms of the Creative Commons Attribution 4.0 International license.

\begin{abstract}
Background: Plectranthus vettiveroides is an aromatic perennial herb, which belongs to family Lamiaceae. The whole plant of $P$. vettiveroides is aromatic, bitter, cooling, febrifuge, diaphoretic, stimulant, diuretic, useful in vitiated conditions of pitta, burning sensation, leprosy, skin diseases, leucoderma, fever, vomiting, diarrhoea, ulcers, stomachic and emmenagogue. In the present investigation morpho-anatomical, preliminary phyto-chemical, physico-chemical parameters and TLC/HPTLC fingerprint of the whole plant of $P$. vettiveroids were carried out and reported. Objective: To carry out morpho-anatomical, phytochemical and TLC/HPTLC studies on dried whole plant of $P$. vettiveroides for authentication/identification. Methods: The morphology, microscopy and phyto-chemical investigation were carried out by following standard methods. Results: Microscopically spiral, reticulated, scalariform and pitted vessels, libriform and septate fibres, multicellular branched covering trichomes, glandular trichomes and silica crystals are the unique diagnostic characteristics in whole plant of $P$. vettiveroides. The preliminary phyto-chemical, physico-chemical parameters and number of spots and $R_{f}$ values of TLC/HPTLC are found to be unique diagnostic characteristics of the plant for identification. Conclusion: The finding of present study is helpful in standardization of formulation consists of whole plant of $P$. vettiveroides as ingredient in their powdered form and also for authentication/ identification of dried whole plant of $P$. vettiveroides.

Key words: P. vettiveroides, Morpho-anatomy, Phytochemistry, TLC/HPTLC finger print, Standardization.
\end{abstract}

\section{INTRODUCTION}

Plectranthus vettiveroides (Jacob) N.P. Singh \& B.D. Sharma (Syn. Coleus vettiveroides Jacob) is an aromatic perennial herb belongs to family Lamiaceae (earlier classified under Labiatae)., ${ }^{1,2}$ The plant is small, bushy, profusely branching, succulent with quadrangular purplish stems and grows upto a meter height. ${ }^{3-5}$ Though being very shrinking population now, it is cultivated at present in Kollidam, a village on the bank of the river Kollidam, Nagai district, Tamilnadu, India. $P$. vettiveroides is an endemic plant to Tamil Nadu and Kerala and is extinct in wild. ${ }^{4,6}$

The whole plant of $P$. vettiveroides is aromatic, bitter, cooling, febrifuge, diaphoretic, stimulant, diuretic, useful in vitiated conditions of pitta, burning sensation, leprosy, skin diseases, leucoderma, fever, vomiting, diarrhoea, ulcers, stomachic, emmenagogue. ${ }^{3,7}$ The roots are found useful in treating allergies, bronchitis, intrinsic hemorrhage, giddiness, headache, rheumatism including carminative properties, insanity and quenching the thirst and in hair growth. ${ }^{3,7}$ The roots of the plant $P$. vettiveroides are more valued in the market due to the medicinal properties. The roots of the plant $P$. vettiveroides are extensively used in many of the Ayurvedic and Siddha formulations like Dhanyapanchaka kvatha curna, Bhunimbadi kavatha curna, Padoladi Ghritham, Kiratadi kvatha curna, Ghanacandanadi kvatha curna, Parpatadi kvatha curna, Vatadyavaleha, Seenthil kudineer, chukku kudineer, Maruthampattai kudineer. ${ }^{8-11}$

In the root extract, 36 chemical constituents were reported and the main constituents are Androstan17-one, 3-ethyl-3-hydroxy-(5a)- (25\%) and -(-) spathulenol( $9 \%){ }^{12}$ The essential oil obtained from root of $P$. vettiveroides $(1.9 \%)$ is orange red colour. There have no reports of the phyto-constituents of leaf and stem so far.

Morpho-anatomical studies are helpful to authenticate the botanical source. Preliminary phytochemical evaluation provides information about presence of phytoconstituents in the plant. Physico-chemical parameters indicate the purity and identity of the plant material. In the present investigation, morpho-anatomical, preliminary phyto-chemical, physico-chemical parameters and TLC/HPTLC fingerprint of the whole plant were carried out and reported. The finding of present study will be helpful in standardization of formulation consisting of whole plant of $P$. vettiveroides as ingredient in their powdered form and also for authentication/identification of dried whole plant of P. vettiveroides.

\section{MATERIALS AND METHODS}

The whole plant of $P$. vettiveroides collected during the month of January 2018 from

Cite this article: Velvizhi D, Nartunai G, Susikumar S, llavarasan R. Morpho-Anatomical, Phytochemical and TLC/HPTLC Studies on Whole Plant of Plectranthus vettiveroides (Jacob) N.P. Singh \& B.D.. Pharmacog J. 2020;12(1):58-65. 
Thirubuvanaimangalam, Kollidam, Nagai district, Tamilnadu, India (GPS data $\left.11^{\circ} 19^{\prime} 35.4^{\prime \prime} \mathrm{N} 79^{\circ} 43^{\prime} 06.5^{\prime \prime} \mathrm{E}\right)$. The voucher specimen of the whole plant of $P$. vettiveroides (Reference code No. C/298A Wp15) were deposited in the department of Pharmacognosy, CSMRADDI, Arumbakkam, Chennai, India for future reference. The collected plant material was washed with water and dried under shade. The shade dried whole plant of $P$. vettiveroides was coarsely powdered (10/44) and utilized for macro-microscopical, physico-chemical, phytochemical and TLC/HPTLC finger print analyses. The morphological, micromorphological and microscopical studies were carried out by standard methods as described in literature. ${ }^{13-15}$ Quantitative analysis for total ash, acid insoluble ash, water and alcohol soluble extractive values, loss on drying at $105^{\circ} \mathrm{C}$ and other solvent extractive values were carried out in triplicate from powder of whole plant according to the standard method recommended. ${ }^{16}$

\section{Preparation of extracts for phytochemical studies}

The shade dried whole plant material was coarsely powdered and $15 \mathrm{~g}$ of plant powder was soaked with n-hexane for $48 \mathrm{hr}$. Then the extract was filtered by using Whatmann No.1 filter paper and concentrated. Similarly, the remaining plant material was successively extracted with chloroform, ethyl acetate and alcohol. All the extracts were qualitatively tested for the presence of various phytochemical constituents of plants by conventional methods. ${ }^{17}$

\section{Method for developing TLC/HPTLC}

\section{Sample preparation}

$4 \mathrm{~g}$ of powdered plant material was soaked with alcohol for overnight. Then extract was boiled for 10 minutes, concentrated, filtered by using Whatmann No.41 filter paper and made up to $10 \mathrm{ml}$ volumetric flask. ${ }^{18,19}$

\section{Instrument}

The CAMAG (Switzerland) HPTLC instrument was operated at relative humidity $53 \pm 5 \%$ and temperature was maintained at $20 \pm 5^{\circ} \mathrm{C}$. The solvent system was optimized with different ratio for mobile phase by trial and error. Qualitative HPTLC analysis was carried out on $10 \times 10$ $\mathrm{cm}$ TLC aluminium plate pre-coated over silica gel $60 \mathrm{~F}_{254}$ with $0.2 \mathrm{~mm}$ thickness. $10 \mu \mathrm{l}$ of samples solution was applied on the plate with $6 \mathrm{~mm}$ band width fitted with a 25 micro liter syringe using CAMAG HPTLC ATS 4 sample applicator. The plate was developed in ascending mode by using the mobile phase ratio toluene: ethyl acetate: Formic acid (8: $2: 0.2 \mathrm{v} / \mathrm{v})$ up to $90 \mathrm{~mm}$ in a twin-trough CAMAG glass chamber previously saturated with mobile phase for 15 minutes at $25^{\circ} \mathrm{C}$. The dried plate visualization was carried out through CAMAG Visualizer at UV $254 \mathrm{~nm}$ and $366 \mathrm{~nm}$, photo-documented and scanned up to 90 $\mathrm{mm}$ plate width by deuterium lamp using a CAMAG TLC scanner 3 with Win CATS Software version 1.4.4. Then the plate was derivatized with $10 \%$ alcoholic-sulphuric acid reagent and heated at $105^{\circ} \mathrm{C}$ when the compounds appeared as colored spots. Photo-documented and scanned at $540 \mathrm{~nm}$ up to $90 \mathrm{~mm}$ by tungsten lamp. ${ }^{18,19}$

\section{RESULTS}

\section{Macroscopy}

The detailed macroscopic characters observed are reported in Table 1 and Figures 1 and 2.

\section{Microscopy}

\section{Root}

Detailed TS of the root shows outer cork consists of compressed cork of rectangular cells filled with dark brown content; followed by cortex consists of up to 8 rows of parenchymatous cells with a few starch grains and sandy crystals; Phloem is narrower zone with obliterated cells; central wider xylem composed of vessels, isolated or occur in radially arranged groups of two or three, parenchyma are mostly vesicentric and contain a few starch grains, fibres are thick walled and many in number, medullary rays are uni- multiseriate medullary rays which run almost parallel to each other and widening towards the phloem (Figure 3).

\section{Stem}

Detailed TS of mature stem shows outer suberised cork with dark brown content; cortex consists of 10-15 rows of tangentially running

\section{Table 1: Macroscopic characters of $P$. vettiveroides dried whole plant.}

\begin{tabular}{ccccc}
\hline S.No. & Macroscopic character & Leaves & Stem & Root and rootlets \\
\hline 1. & Colour, odour and taste & Gray, aromatic and bitter & Brownish black, aromatic and bitter & Brownish black, aromatic and bitter \\
2. & Size and shape & Upto $7 \mathrm{~cm}$ long with petiole & Upto $7 \mathrm{~mm}$ width, angular with furrow & Tap root upto $5 \mathrm{~mm}$ lateral roots upto 1mm width \\
3. & Texture and fracture & Dull and soft & furrowed and splintery & Smooth and short
\end{tabular}

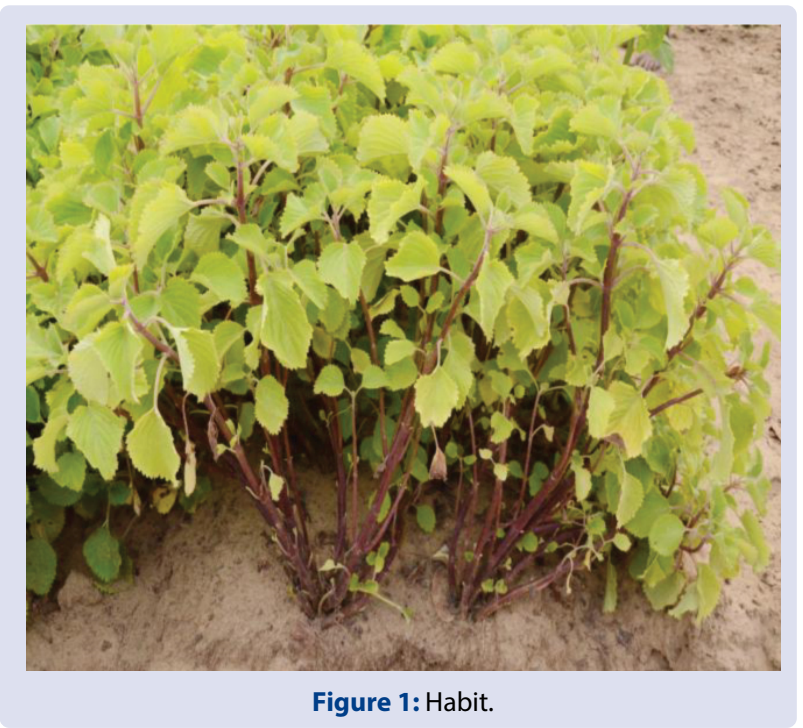



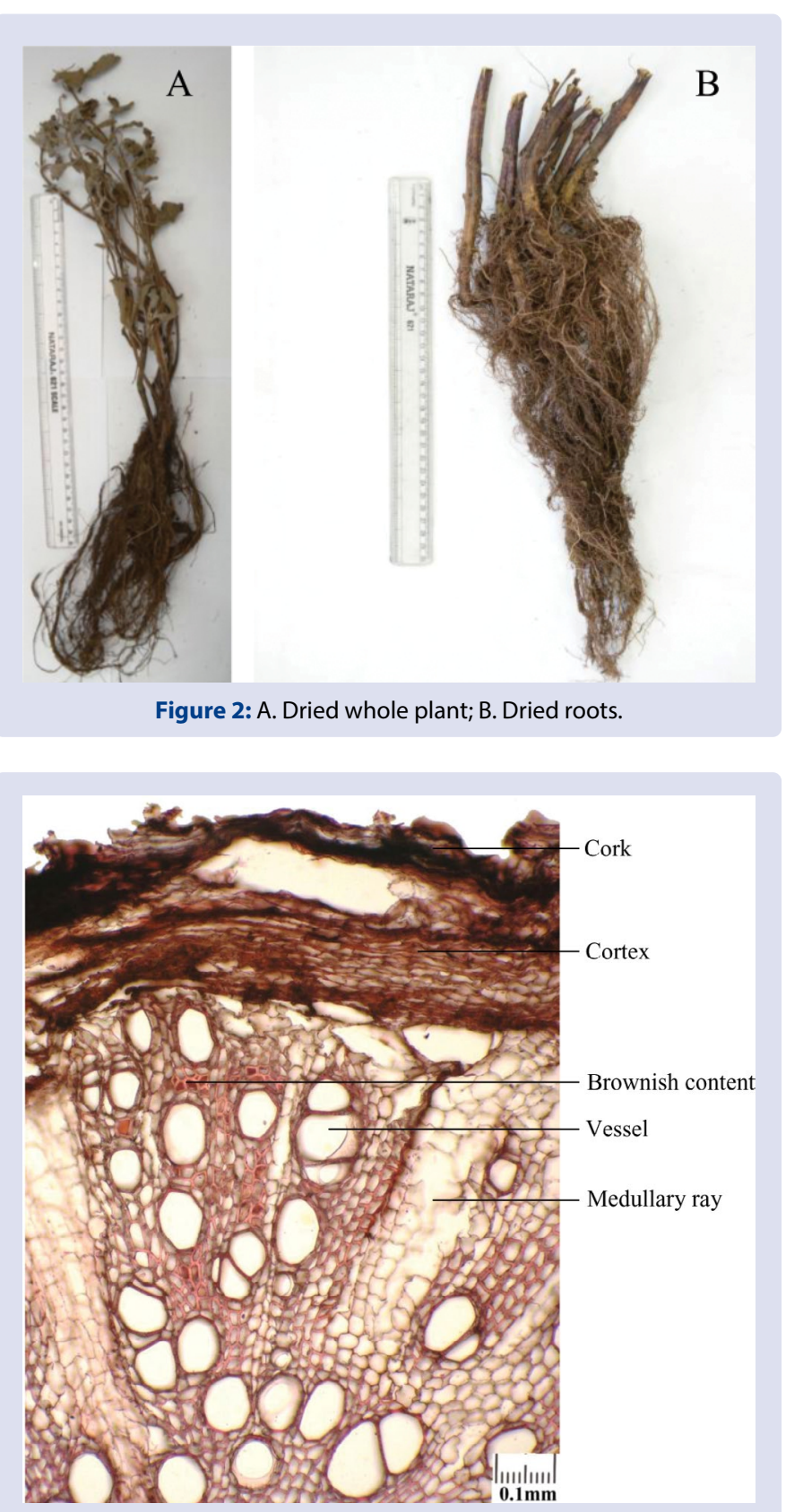

Figure 3: Transverse section of $P$. vettiveroides root.

parenchymatous cells, embedded with group of cortical fibres, followed by narrow zone of phloem consists of obliterated cells; followed by wide zone of xylem consists of isolated or radially arranged rows of vessels, parenchyma which are mostly vesicentric, thin walled fibres occupying the major area of the xylem (Figure 4).

\section{Leaves}

\section{Petiole}

Detailed TS of the petiole is oval in outline with a concavity on upper surface, covered with numerous covering and glandular trichomes, a single layer of epidermis, 3 to 6 rows of collenchymatous hypodermis; the ground tissue is parenchymatous, wide; a circle of discontinuous vascular bundles and parenchymatous pith (Figure 5).

\section{Midrib}

Detailed TS of midrib shows single layer of upper and lower epidermis covered with thin cuticle, bearing numerous covering and glandular trichomes, covering trichome uni and multicellular, glandular trichomes sessile, 2-4 rows of collenchymatous hypodermis, parenchymatous ground tissue embedded with group of vascular bundles (Figure 6).

\section{Powder microscopy}

The powder microscopic characters are shown in Figure 7.

Physico-chemical and preliminary phyto-chemical analysis

The physico-chemical and preliminary phyto-chemical analyses of whole plant of $P$. vettiveroides are presented in Tables 2 and 3, respectively.

\section{TLC/HPTLC fingerprint}

The HPTLC finger print profile of alcohol extract of the whole plant showed 15 spots at UV $254 \mathrm{~nm}$ with 2 spots appeared major with an area of more than $10 \%$ the $\mathrm{R}_{\mathrm{f}}$ values, 18 spots with three spots appeared major with an area of more than $10 \%$ the $\mathrm{R}_{\mathrm{f}}$ values shown at UV 366 $\mathrm{nm}$ and after derivatised with alcoholic sulfuric acid reagent the plate

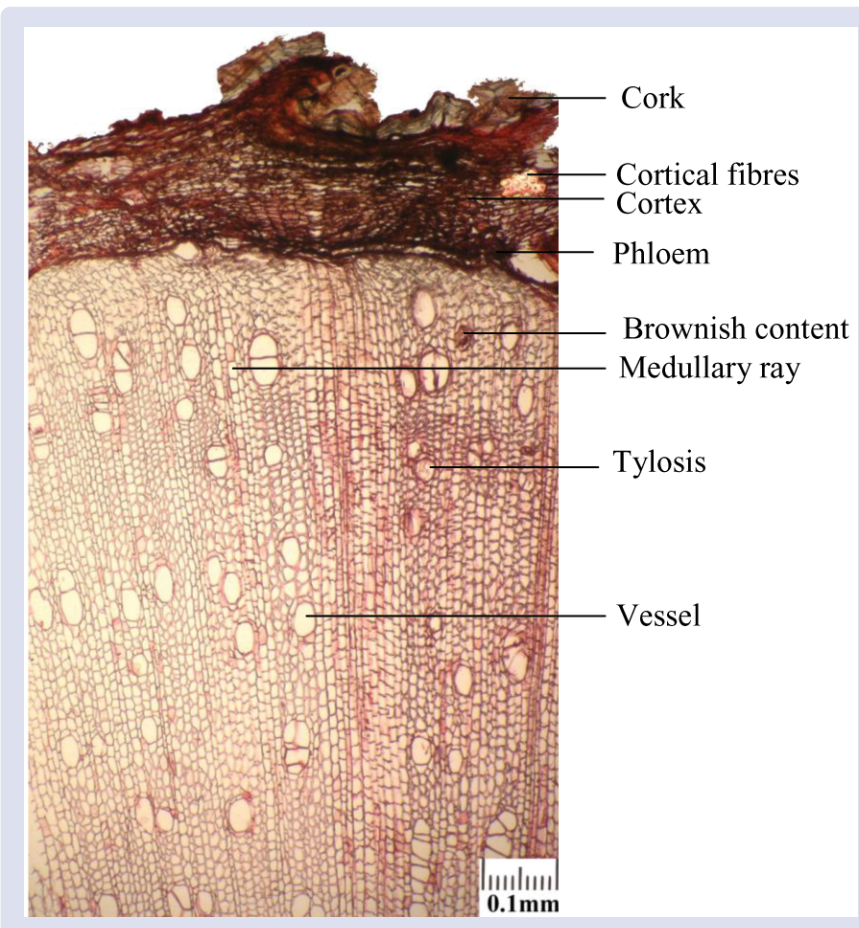

Figure 4: Transverse section of $P$. vettiveroides stem.

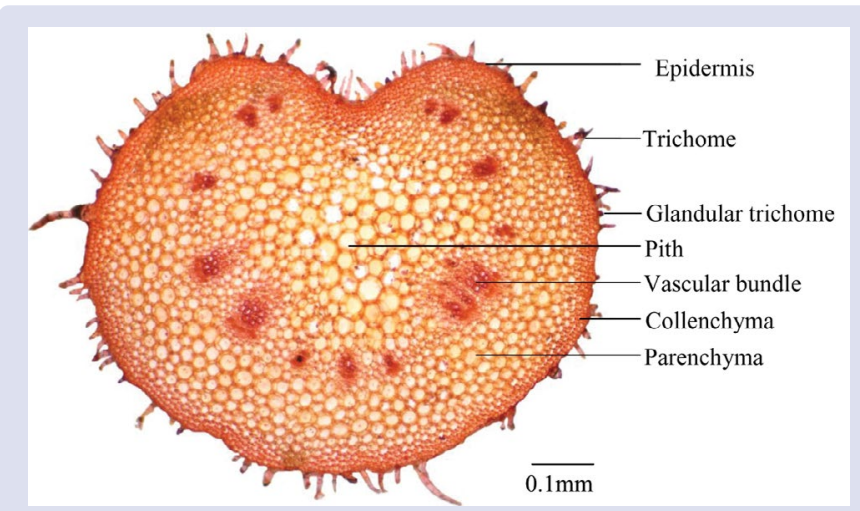

Figure 5: Transverse section of $P$. vettiveroides petiole. 

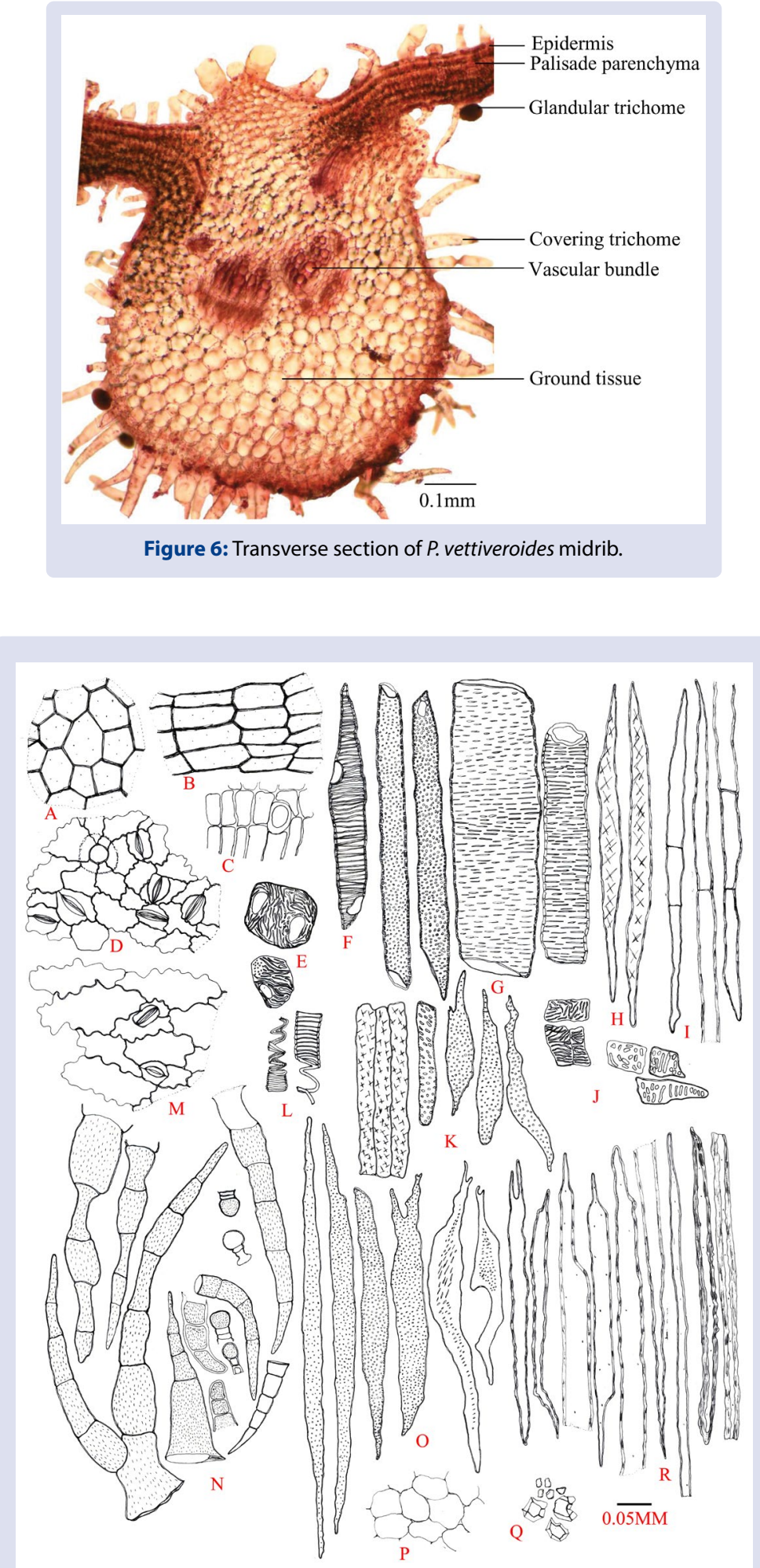

Figure 7: Powder microscopy of $P$. vettiveroides whole plant. A, root cork cells in surface view; B, root cork cells in sectional view; $\mathbf{C}$, epidermal cells of young stem in surface view; $\mathbf{D}$, lower epidermis with stomata and wavy anticlinal walls; $\mathbf{E}$, reticulated vessels; $\mathbf{F}$, scalariform vessels; $\mathbf{G}$, pitted vessels; $\mathbf{H}$, fibres with tertiary thickening; I, septate fibres from leaf; J, pitted parenchyma; K, tracheids; $\mathbf{L}$, spiral vessels; $\mathbf{M}$, upper epidermis with stomata and wavy anticlinal walls; $\mathbf{N}$, multicelluar branched covering and glandular trichomes; $\mathbf{O}$, forked, pegged fibre tracheids; $\mathbf{P}$, parenchyma cells; $\mathbf{Q}$, silica crystals; $\mathbf{R}$, thin and thick walled, forked, pegged fibres. 
Table 2: Physico-chemical analysis of whole plant of $P$. vettiveroides.

\begin{tabular}{llc}
\hline S. No. & Physico-chemical Parameters $(n=3) \pm S D$ & Mean \\
\hline 1 & Loss on drying at $105^{\circ} \mathrm{C}$ & $9.94 \pm 0.46$ \\
2 & Total ash & $23.0 \pm 0.22$ \\
3 & Acid insoluble ash & $22.2 \pm 0.28$ \\
4 & Water insoluble ash & $22.6 \pm 0.21$ \\
5 & Alcohol soluble extractive & $6.82 \pm 0.42$ \\
6 & Water soluble extractive & $17.23 \pm 0.66$ \\
7 & Hexane soluble extractive & $1.80 \pm 0.18$ \\
8 & Chloroform soluble extractive & $3.24 \pm 0.44$ \\
9 & Ethyl acetate soluble extractive & $3.86 \pm 0.31$ \\
\hline
\end{tabular}

Table 3: Preliminary phyto-chemical analysis of whole plant of $P$. vettiveroides.

\begin{tabular}{ccccc}
\hline \multirow{2}{*}{ Phytochemical tests } & \multicolumn{3}{c}{ Whole plant } \\
\cline { 2 - 5 } & H & C & EA & E \\
\hline Terpenoids & + & + & + & + \\
Flavonoids & - & + & + & + \\
Lignin & - & + & + & + \\
Cardiac glycosides & - & - & + & - \\
Sterols & + & + & - & + \\
Tannins & - & - & - & + \\
Glycosides & - & - & - & + \\
Alkaloids & - & - & + & + \\
Coumarin & - & + & + & + \\
\hline
\end{tabular}

H- Hexane, C- Chloroform, EA- Ethyl acetate, E- Ethanol extract

(+) - Present; (-) - Absent

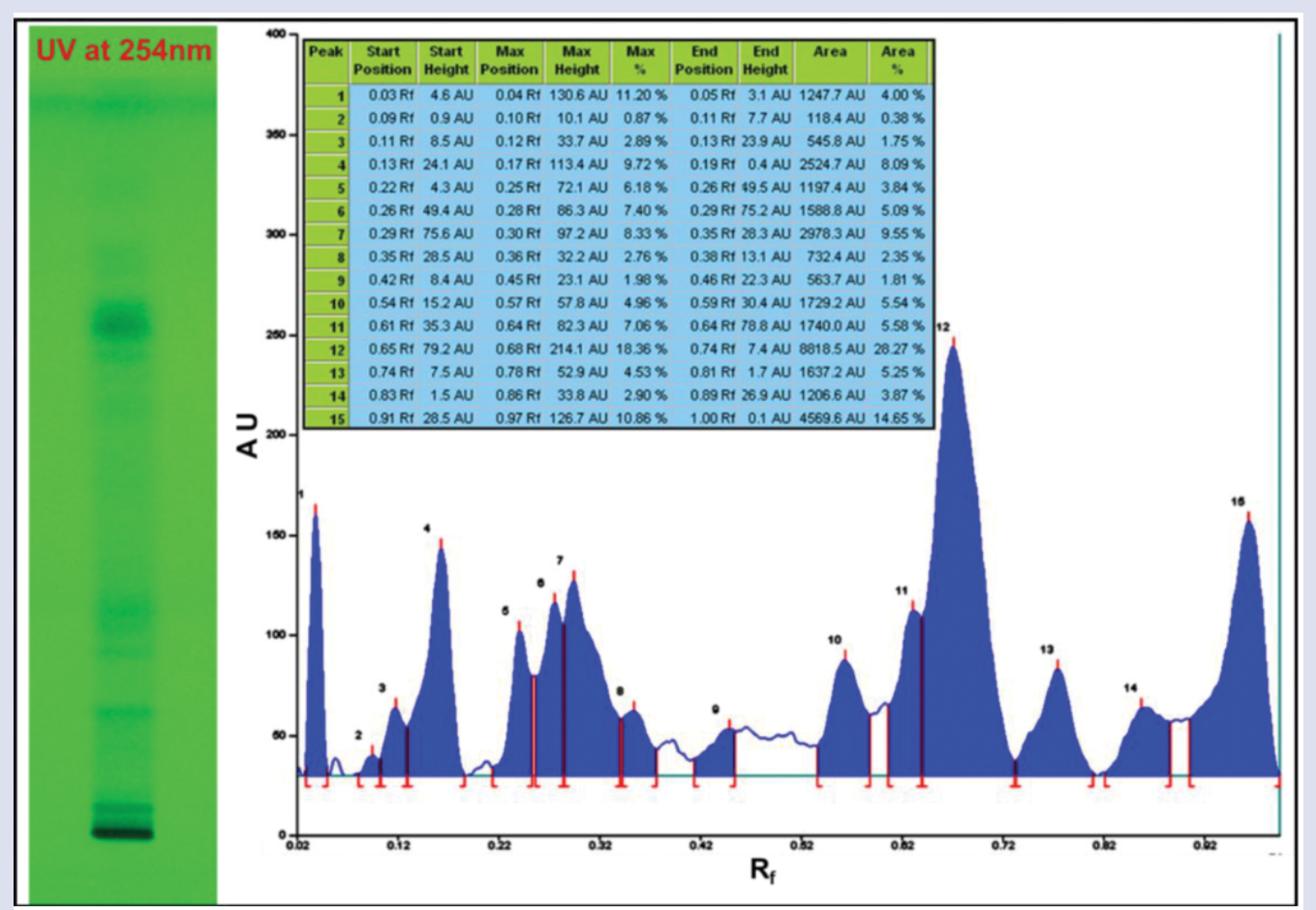

Figure 8: TLC/HPTLC fingerprint of alcoholic extract of whole plant of $P$. vettiveroides at UV $254 \mathrm{~nm}$.

scanned at $540 \mathrm{~nm}$ showed 17 spots with four spots appeared major with an area of more than $10 \%$ (Figures 8 -10).

\section{DISCUSSION}

In Tamil Nadu both P. vettiveroides and Vetiveria zizanoides are referred and sold in the same names, Kuruver or Vettiver. The roots of Vetiveria zizanoides are being used as an adulterant due to the non-availability of $P$. vettiveroides. It was noticed that the raw drug being sold as
'Kuruver' in the market was actually the roots of V. zizanoides. Thus, the confusion between this two roots exists in literature and as well as in the market. Scarcity in availability of $P$. vettiveroides roots is the reason for adulteration, the plenty of available roots of $V$. zizanoides which looks similar in appearance is used as adulterant.

Pharmacognostic characters of herbal drugs play an important role since particular macro-microcopic features are unique for each plant. The macroscopic and microscopic studies of the herbs should be 


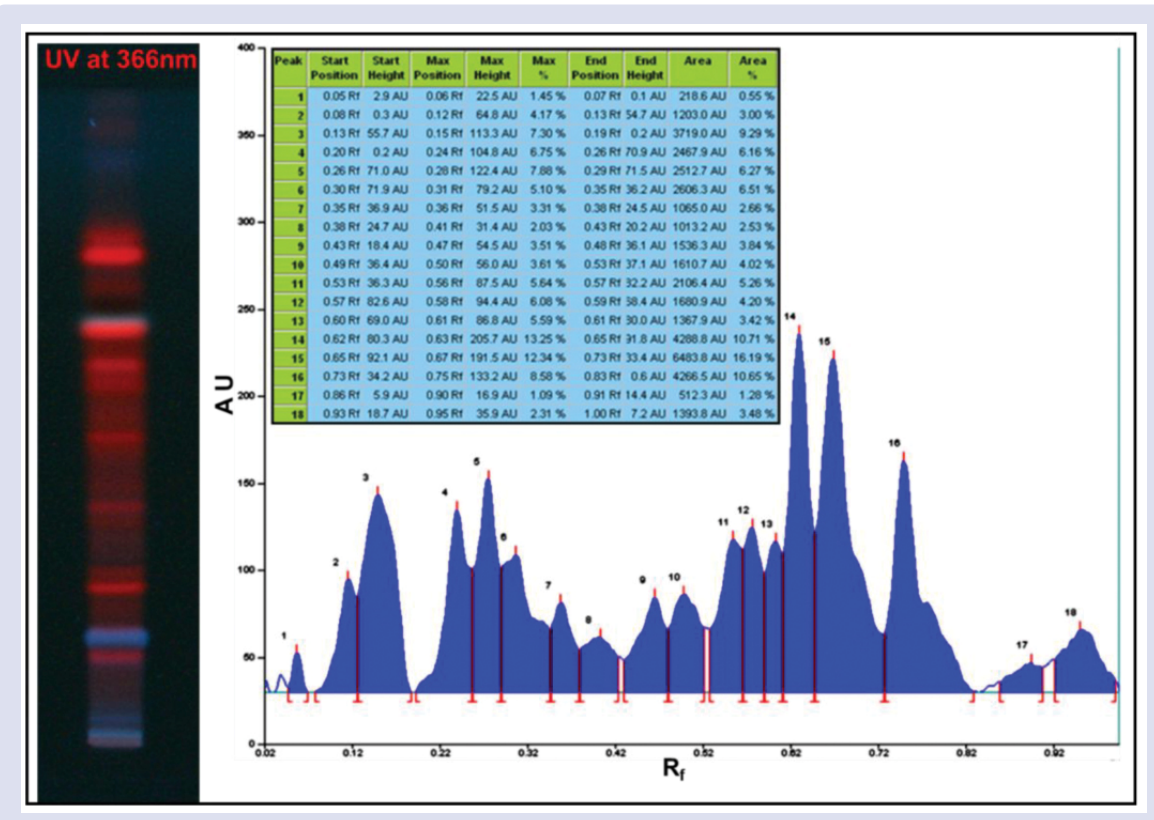

Figure 9: TLC/HPTLC fingerprint of alcoholic extract of whole plant of $P$. vettiveroides at UV $366 \mathrm{~nm}$.

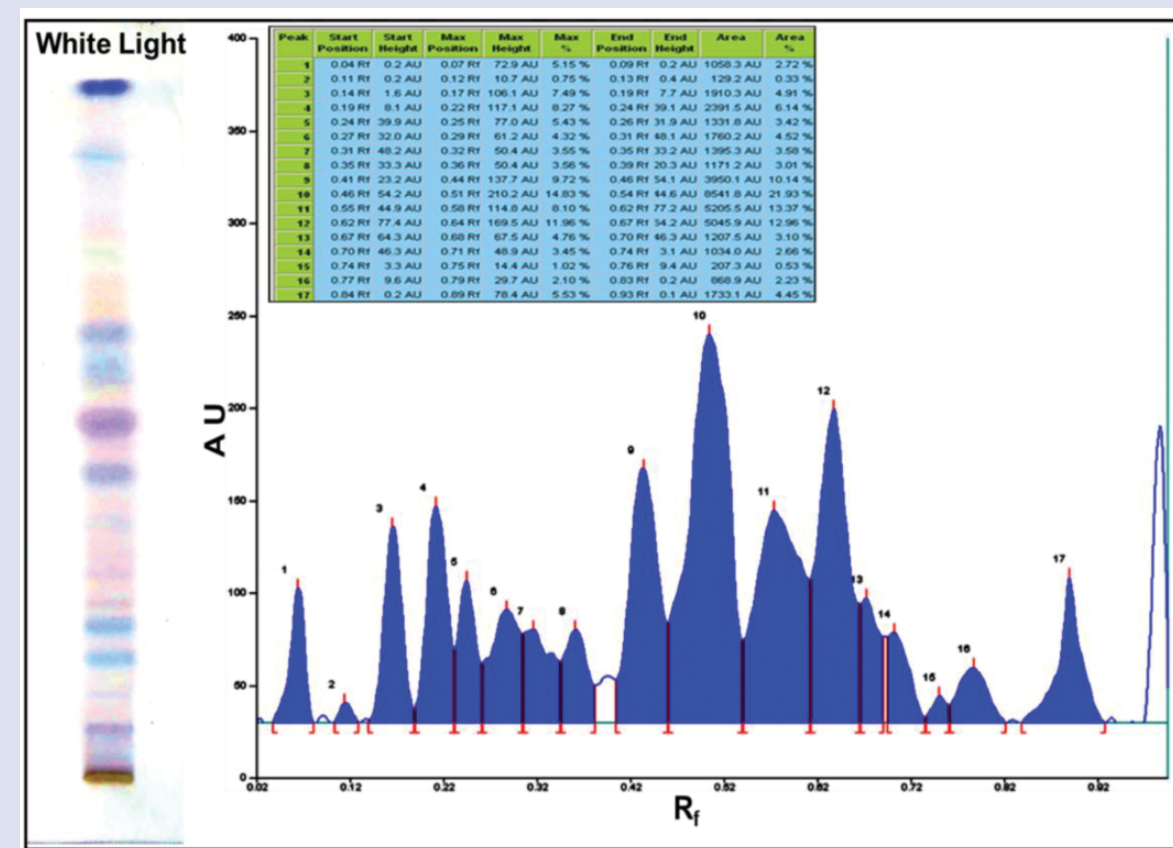

Figure 10: TLC/HPTLC fingerprint of alcoholic extract of whole plant of $P$. vettiveroides at $540 \mathrm{~nm}$.

the first and fundamental step to authenticate the botanical source. Proceeding for chemical methods of standardization, preclinical and clinical evaluation will bear no value if authentic drugs are not used. Macro-microscopic evaluation is simple and cost effective..$^{20,21}$ The high values of loss on drying denote the presence of high water and volatile content. Water soluble extractive value shows the presence of more amounts of polar compounds. ${ }^{16}$ The high values of acid insoluble ash and powder microscopy is the indicative of high level of silica present in the plant material as it is grown in sandy river bed, the plant absorbs silica and store it in inner cells. TLC/HPTLC fingerprint of alcoholic extract of whole plant of $P$. vettiveroides provides a suitable method for monitoring the identity, purity and also standardization of the drug.
From the results of this study, it has been found the dried whole plant of $P$. vettiveroides can be easily identified macro-microscopically and phyto-chemically. This study sets specific morpho-anatomical, preliminary phytochemical and physico-chemical protocol and TLC/ HPTLC fingerprint on dried whole plant and powder of $P$. vettiveroides and could also be helpful in standardization of formulation containing whole plant of $P$. vettiveroides as ingredient in powdered form.

\section{CONCLUSION}

Morpho-anatomical, preliminary phytochemical, physico-chemical and TLC/HPTLC studies on whole plant of $P$. vettiveroides has been carried out and reported. Findings of this study may be useful for 
authentication/identification of whole plant of $P$. vettiveroides in crude drug and also in powdered formulation.

\section{ACKNOWLEDGEMENT}

The authors are very grateful to the Director General, Central Council for Research in Ayurvedic Sciences, New Delhi, for his encouragement and providing opportunity to conduct this study.

\section{CONFLICTS OF INTEREST}

The authors declare no conflicts of interest.

\section{ABBREVIATIONS}

Fam: Family; Fig: Figure; CSMRADDI: Captain Srinivasa Murthy Regional Ayurveda Drug Development Institute; TLC/HPTLC: Thin Layer Chromatography/High performance Thin layer Chromatography.

\section{REFERENCES}

1. Willis JC. A Dictionary of the Flowering plants and Ferns. Eighth edition, Dehra Dun: International Book Distributors, 1982;272

2. The Plant List (2013), version 1.1. Published on the Internet; http://www. theplantlist.org/tpl1.1/record/kew-158576 (accessed on 22nd February 2018).

3. Warrier PK, Nambiar VPK, Ramankutty C. Indian medicinal plants: A compendium of 500 species. Madras: Orient Longman 1997;4:318-9.

4. Saraswathy A, Amala K, Arunmozhi Devi. Coleus vettiveroides K.C.Jacob; Botany and Pharmacognosy. Indian J Tradit Know. 2011;10(4):636-42.

5. Manilal KS, Van Rheede's. Hortus Malabaricus (English edn) with Annotations and Modern Botanical Nomenclature. Thiruvananthapuram: University of Kerala. 2003;9:249-51.

6. Mamatha B. Soil and Nutrient Management Studies in Coleus vettiveroides Jacab. Ph.D. Thesis, Department of Soil Science and Agricultural Chemistry, University of Agricultural Sciences Bangalore, 2009.

7. Yoganarasimhan SN. Medicinal plants of India- Tamil Nadu. Banglore: Cyber media, 2000;424.
8. Presannakumaran PN, Jayasekhar P. A QHPTLC Method for the estimation of Coscinium fenestratum in Padoladi Ghritham- An Ayurvedic Polyherbal formulation. Int J Pharm Res Rev. 2017;6(2):1-11.

9. The Ayurvedic Formulary of India, Part (III) (First edition). Department of Ayurveda, Yoga \& Naturopathy, Unani, Siddha and Homoepathy (AYUSH), New Delhi: The Controller of Publications. 2011;62:79-81\&87.

10. Harihara Mahadevan M, Vanmathi KP. Literature review on siddha herbal formulation (Kudineer) available for the management of dengue. Int J Pharmacol and Clin Sci. 2016;5(3):90-6.

11. Nisheeda BA, Safeer PM, Sreekumar S, Biju CK, Seeja G, Manivannan C. A review on Plectranthus vettiveroides: An endemic to South Indian high value aromatic medicinal plant. J Pharm Biol Sci. 2016;11(2):1-11.

12. Saraswathy A, Mercy Lavanya S. Chemical composition and Antibacterial activity of the essential oil from the roots of Coleus vettiveroides K.C.Jacob. Int J Pharm Biol Sci. 2013;3(3):212-7.

13. Anonymous, The Ayurvedic Pharmacopoeia of India, part-I, Volume-VI, First Edition, Government of India, Ministry of Health and Family Welfare. Department of AYUSH, New Delhi, 2008;233-42.

14. Iyengar MA. Pharmacognosy of Powdered Crude Drugs. Manipal Power press: Manipal, 1980

15. Sass JE. Botanical Microtechnique, Oxford and IBH Publishing co. Calcutta, 1958.

16. Anonymous. Quality Control Methods for Medicinal Plant Materials. World Health Organization, Geneva, 1998.

17. Harborne JB. Phytochemical Methods. 2nd ed. London: Chapman \& Hall, 1973.

18. Sethi PD. High Performance Thin Layer Chromatography, $1^{\text {st }}$ Edn., Vol.X, CBS Publishers and Distributors, New Delhi, 1996.

19. Wagner H, Bladt S. Plant Drug Analysis A Thin Layer Chromatography Atlas, 2nd Edn, Germany, Springer-Verlag, 1996.

20. Nartunai G, Arunachalam C, Maheswari B, Venkata Narasimhaji C, Kusuma G, llavarasan R. Pharmacognostical and Phytochemical Evaluation of a Polyherbal Ayurvedic Formulation Trikatu Churna. Journal of Ayurveda Medical Sciences. $2016 ; 1(1): 34-40$.

21. Susikumar S, Nartunai G, Arunachalam C, Ilavarasan R. Macro-microscopic atlas on heartwood of Santalum album L. (Sandalwood). Pharmacognosy Journal. 2018:10(4):731-4

\section{GRAPHICAL ABSTRACT}

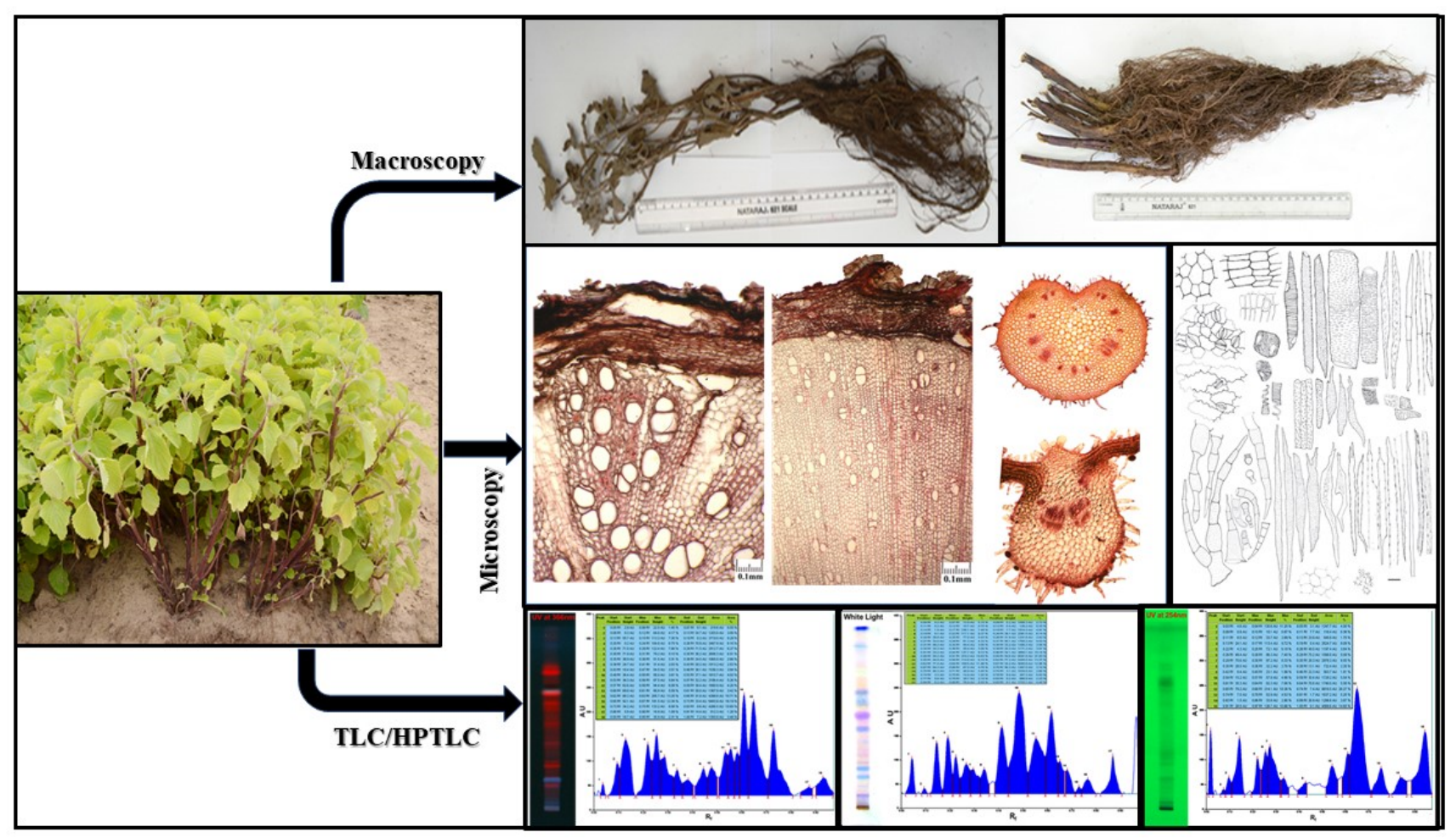




\section{SUMMARY}

- Plectranthus vettiveroides (Jacob) N.P. Singh \& B.D. Sharma (Syn. Coleus vettiveroides Jacob) is an aromatic perennial herb belongs to family Lamiaceae.

- The whole plant of $P$. vettiveroides is aromatic, bitter, cooling, febrifuge, diaphoretic, stimulant, diuretic, useful in vitiated conditions of pitta, burning sensation, leprosy, skin diseases, leucoderma, fever, vomiting, diarrhoea, ulcers, stomachic and emmenagogue.

- The roots of the plant P.vettiveroides is more valued in the market due to its medicinal properties

- The roots of Vetiveria zizanoides is being used as an adulterant due to the non-availability of $P$. vettiveroides in the raw drug market.

- Hence, the Macro-microscopical, Preliminary phytochemical, Physico-chemical and TLC/HPTLC studies on dried whole plant of $P$. vettiveroides was carried out and reported.

- Findings of the study helpful in authentication of raw drug and standardization of formulations containing $P$. vettiveroides whole plant as ingredient.

\section{ABOUT AUTHORS}

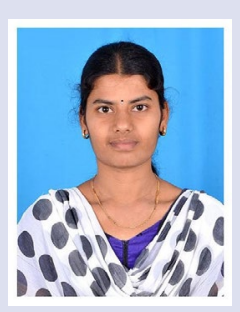

Velvizhi Dharmalingam is a Research Scholar at Captain Srinivasa Murthy Regional Ayurveda Drug Development Institute, Chennai - 600 106, Under CCRAS, Ministry of AYUSH, Govt. of India. She has worked under the IMR project titled on "Development of Marker Compounds from Medicinal Plants" and has experience in the area of Phytochemistry and Herbal Drug Standardization.

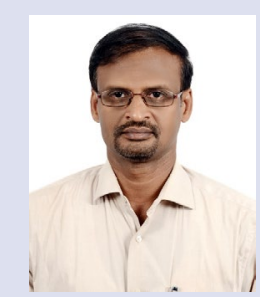

Nartunai Govindarajan is a Research Officer (Pharmacognosy) at Captain Srinivasa Murthy Regional Ayurveda Drug Development Institute, Chennai - 600 106, Under CCRAS, Ministry of AYUSH, Govt. of India. His research focused on developing quality standards for medicinal plants used in Ayurveda. He has projects in Intra Mural and Extra Mural Research Schemes. Has experience in the area of Pharmacognosy, developed monographs for Ayurvedic Pharmacopoeia of India and Quality Standards for Indian Medicinal Plants by ICMR.

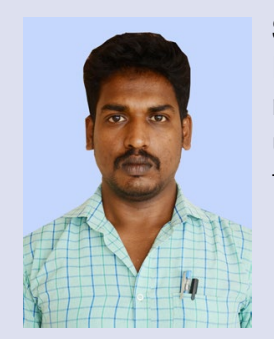

Susikumar Sundaramoorthy is a Research Scholar at Captain Srinivasa Murthy Regional Ayurveda Drug Development Institute, Chennai - 600 106, Under CCRAS, Ministry of AYUSH, Govt. of India. His doctoral research focused on developing quality standards for medicinal plants used in Ayurveda. He has worked under the ICMR project titled on "Quality Standards for Indian Medicinal Plants and preparation of monograph thereon". Has experience in the area of Pharmacognosy and Botany.

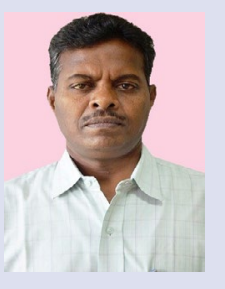

Ilavarasan Raju is an Assistant Director (S-4) Institute in-charge at Captain Srinivasa Murthy Regional Ayurveda Drug Development Institute, Chennai - 600 106, Under CCRAS, Ministry of AYUSH, Govt. of India. He has vast experience in the area of Pharmacology and Herbal Drug Standardization. He has projects in Intra Mural and Extra Mural Research Schemes. Guiding students for Ph.D., studies of various universities. Have publications in National and International Journals in his credit.

Cite this article: Velvizhi D, Nartunai G, Susikumar S, Ilavarasan R. Morpho-Anatomical, Phytochemical and TLC/HPTLC Studies on Whole Plant of Plectranthus vettiveroides (Jacob) N.P. Singh \& B.D.. Pharmacog J. 2020;12(1):58-65. 